\title{
Late Caddo Titus Phase Ceramics from the McKay Site (41TT730), Titus County, Texas
}

Timothy K. Perttula

Heritage Research Center, Stephen F. Austin State University

Follow this and additional works at: https://scholarworks.sfasu.edu/ita

Part of the American Material Culture Commons, Archaeological Anthropology Commons, Environmental Studies Commons, Other American Studies Commons, Other Arts and Humanities Commons, Other History of Art, Architecture, and Archaeology Commons, and the United States History Commons

Tell us how this article helped you.

This Article is brought to you for free and open access by the Center for Regional Heritage Research at SFA ScholarWorks. It has been accepted for inclusion in Index of Texas Archaeology: Open Access Gray Literature from the Lone Star State by an authorized editor of SFA ScholarWorks. For more information, please contact cdsscholarworks@sfasu.edu. 


\section{Late Caddo Titus Phase Ceramics from the McKay Site (41TT730), Titus County,}

Texas

\section{Creative Commons License}

(c) (1) (8)

This work is licensed under a Creative Commons Attribution-NonCommercial 4.0 International License 


\section{Late Caddo Titus Phase Ceramics from the McKay Site (41TT730), Titus County, Texas}

\section{Timothy K. Perttula}

\section{Introduction and Site Setting}

The McKay site (41TT730) is a multi-component site on an upland landform about $100 \mathrm{~m}$ east of Hart Creek, a southward-flowing tributary of Big Cypress Creek. During house construction in 1990, archaeological deposits covering about 5 acres of the landform were exposed, and these deposits include occupations that date from as early as the Paleoindian and Archaic periods to as late as Early to Late Caddo period times (ca. A.D. 900-1680).

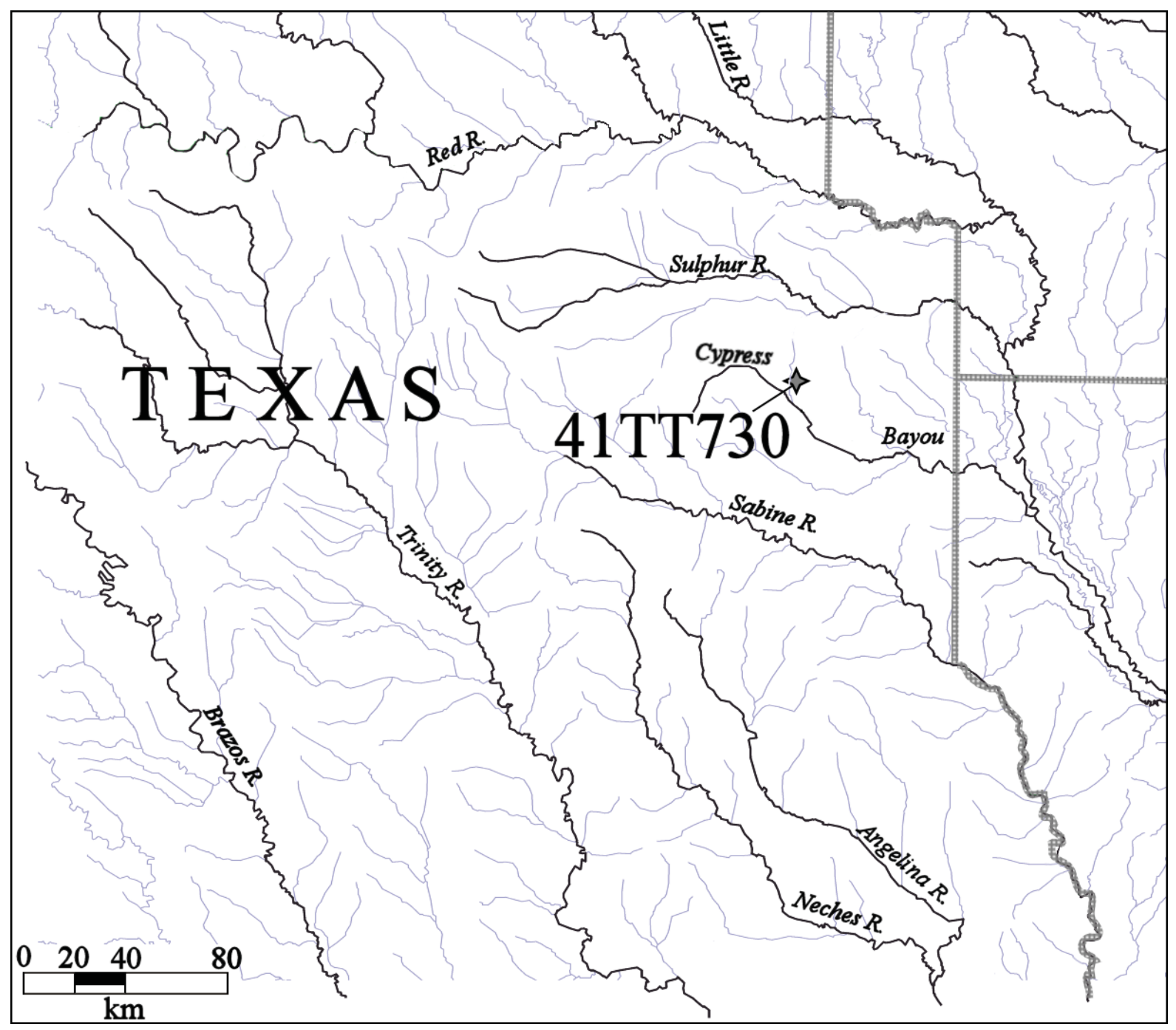

Figure 1. The general location of the McKay site in East Texas. 
The principal ancestral Caddo component at the McKay site belongs to the Late Caddo period Titus phase, dating generally from ca. A.D. 1430-1680. This component included both habitation deposits as well as burial features in the area of house pad construction; the habitation area is at least $50 \mathrm{~m}$ northwest of the cemetery. At least 17 burials were excavated there by local workers after the cemetery had been exposed by land leveling, and these burials included ceramic vessels as funerary offerings, along with Talco arrow points, two ground stone celts, and a ceramic elbow pipe. The workers removed an unknown number of exposed and complete vessels, although portions of a few of these vessels were documented (see below). Broken vessels were scattered and mixed into the fill of the house pad.

\section{Ceramic Assemblage}

The ceramic assemblage from the McKay site includes 104 sherds from plain ware ( $\mathrm{n}=55)$, utility ware $(n=33)$, and fine ware $(n=16)$ vessels uniformly tempered with grog (crushed sherds), as well as substantial rim and/or body sherds from Vessel Sections 1 and 2. The plain to decorated sherd ratio of this assemblage is a low 1.12, consistent with a Late Caddo period assemblage in this part of East Texas.

Vessel Section 1 includes five rim sherds. It is from a Ripley Engraved, var. Galt carinated bowl with a central ticked circle, a slanted scroll line, and upper and lower scroll fill zones with circles and vertical bracket elements (Figure 2a). Vessel Section 2, consisting of nine rim sherds and five body sherds, is from a Ripley Engraved, var. McKinney vessel with central circle elements and horizontal engraved scroll lines with excised pendant triangles (Figure 2b).

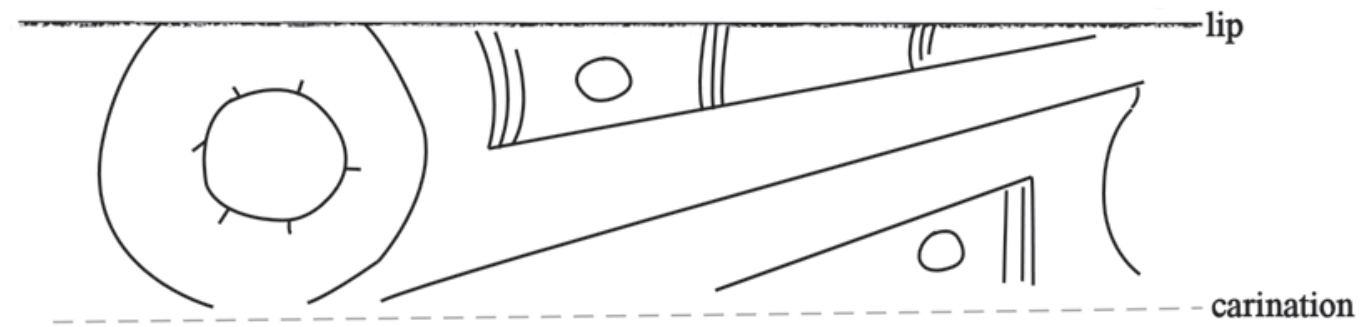

a

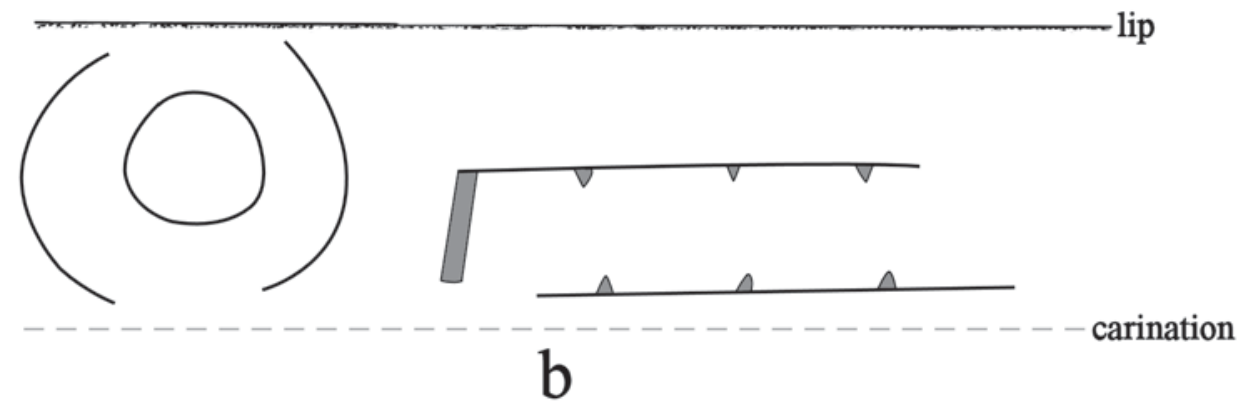

Figure 2. Decorative elements on Vessel Sections 1 and 2 at the McKay site (41TT730).

In the sherd assemblage, the plain wares include three rims with everted and rounded rims and lips, 46 body sherds, and six base sherds. The utility wares are represented by seven rims and 26 body sherds, with the rims coming from Karnack Brushed-Incised and Maydelle Incised jars (Table 1 and Figure 3b, e-h). There are also Harleton Appliqued, Bullard Brushed, and Mockingbird Punctated rim and body sherds (Figure 3a) in the McKay site ceramic assemblage. 
Table 1. Utility ware sherds from the McKay site (41TT730).

Identified sherds by method and element $\quad$ No.

Harleton Appliqued body sherd

1

parallel brushed body sherds

parallel brushed-incised body sherds

Karnack Brushed-Incised rims

cross-hatched incised rim $(n=2)$ and body $(n=3)$ sherds

diagonal incised rim sherd

parallel incised body sherds

6

2

4

straight line incised body sherds

1

5

4

zoned incised-tool punctated-filled body sherds

2

fingernail punctated rows on rim $(n=1)$ and body $(n=2)$ sherds

3

Totals

33

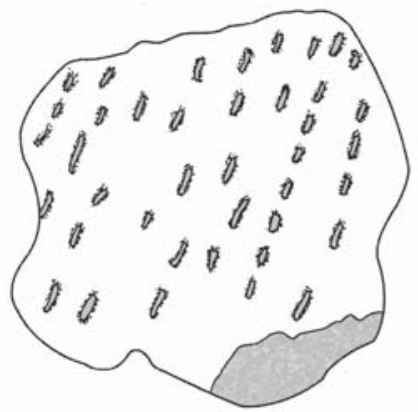

a

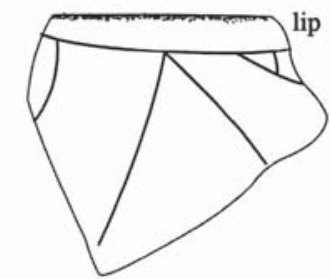

d

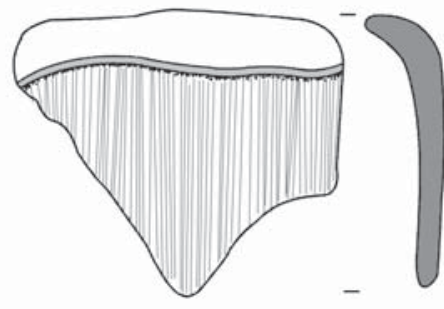

$\mathrm{g}$
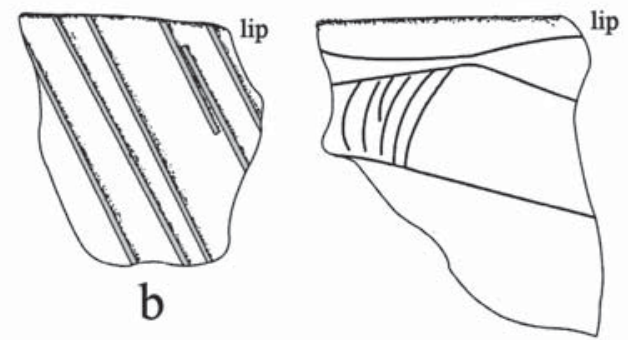

C

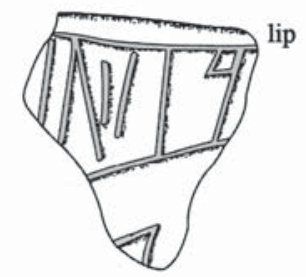

e

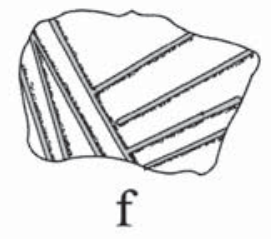

f
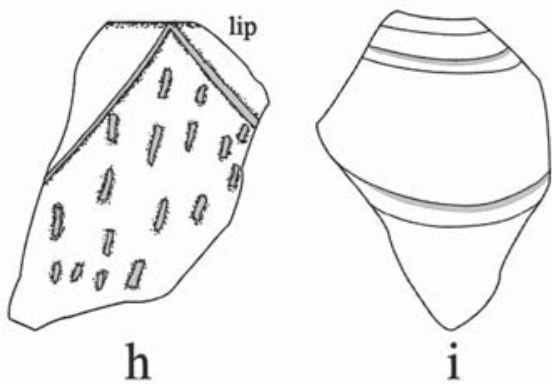

Figure 3. Selected decorative elements on sherds from the McKay site (41TT730). 
The fine ware sherds are from Ripley Engraved rim $(n=8)$ and body $(n=7)$ sherds (see Figure $3 c-d)$, along with one Keno Trailed vessel sherd with curvilinear trailed lines (see Figure 3i). One of the Ripley Engraved rim sherds has an interlocking scroll element (Ripley Engraved, var. Pilgrims), and four other sherds have portions of engraved scrolls; the specific variety of these sherds or the other fine ware sherds in the assemblage could not be determined.

\section{Summary and Conclusions}

The McKay site was discovered during house pad construction in 1990. That work led to the discovery of ancestral Caddo habitation and cemetery areas, and before the work was done, at least 17 burials were dug by local workers who carried off the whole or complete funerary offerings. A small sample of the ancestral Caddo artifacts from the site were obtained for study, and this article is the result.

The ceramic sherds and vessel sections from the McKay site (41TT730) are consistent with a Titus phase ceramic assemblage in the Big Cypress Creek basin in East Texas (Perttula 2013:195-196 and Figures 12 and 13). Such assemblages date from ca. A.D. 1430-1680, during the Late Caddo period, but the presence of both Ripley Engraved, var. McKinney and Keno Trailed vessel sherds, as well as Talco arrow points with an unknown number of burials, suggests the principal Caddo occupation of the site took place in the $17^{\text {th }}$ century A.D.

\section{Acknowledgments}

Thanks to Bo Nelson for access to the collection of artifacts known from the McKay site, and for recording the site. Lance Trask prepared the figures for this article.

\section{References Cited}

Perttula, T. K.

2013 Caddo Ceramics in East Texas. Bulletin of the Texas Archeological Society 84:181-212. 